\title{
Arabinoxylan/Cellulose Nanocrystal Hydrogels with Tunable Mechanical Properties
}

\author{
Malika Talantikite*, Nadège Leray, Céline Moreau, Bernard Cathala \\ UR1268 Biopolymères Interactions Assemblages, INRA, Rue de la géraudière, 44316, \\ Nantes, France \\ Corresponding author: malika.talantikite@inra.fr
}

\section{Figures}

Figure S1. POM images of gels formed with $10 \mathrm{~g} / \mathrm{L} \mathrm{CNC}$ and (a) $7.5 \mathrm{~g} / \mathrm{L}$, (b) $10 \mathrm{~g} / \mathrm{L}$ and (c)12 g/L AX.

Figure S2. (a) Viscosity vs. concentration for CNC suspensions and AX solutions; (b) Viscosity measurements for solutions containing $10 \mathrm{~g} / \mathrm{L} \mathrm{CNC}$ in the presence of $\mathrm{AX}$ at different concentrations at $20^{\circ} \mathrm{C}$.

Figure S3. (a) $G^{\prime}$ and $G^{\prime \prime}$ variation as a function of \% strain; and (b) variation of $G^{\prime}$ and $G^{\prime \prime}$ as a function of time after breaking for $10 \mathrm{~g} / \mathrm{L} \mathrm{CNC}+10 \mathrm{~g} / \mathrm{L} \mathrm{AX}$ at $20^{\circ} \mathrm{C}$.

Figure S4. The effect of $\mathrm{NaCl}$ addition on the viscosity of a solution containing $10 \mathrm{~g} / \mathrm{L} \mathrm{CNC}+$ $5 \mathrm{~g} / \mathrm{L} \mathrm{AX}$ at $20^{\circ} \mathrm{C}$, with photos of the resulting mixtures showing the salt effect.

Figure S5. POM images of solution containing $10 \mathrm{~g} / \mathrm{L} \mathrm{CNC}$ and $10 \mathrm{~g} / \mathrm{L} \mathrm{AX}(\mathrm{a}, \mathrm{b})$ before the action of the enzyme, and (c, d) after the action of enzyme with and without the retardation plate. 


\section{Supplementary Figures}
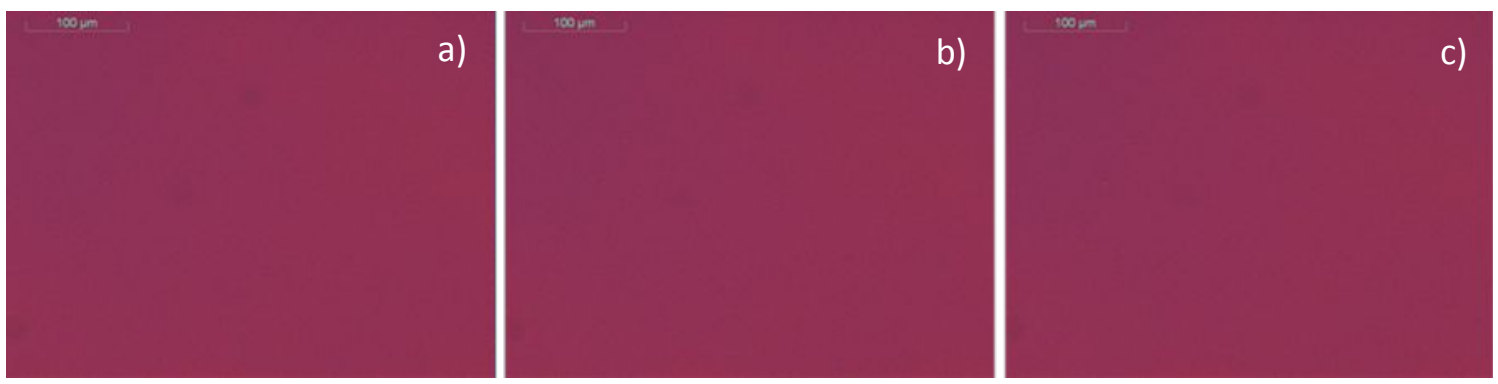

Figure S1. POM images of gels formed with $10 \mathrm{~g} / \mathrm{L} \mathrm{CNC}$ and (a) $7.5 \mathrm{~g} / \mathrm{L}$, (b) $10 \mathrm{~g} / \mathrm{L}$ and (c) $12 \mathrm{~g} / \mathrm{L} \mathrm{AX}$.
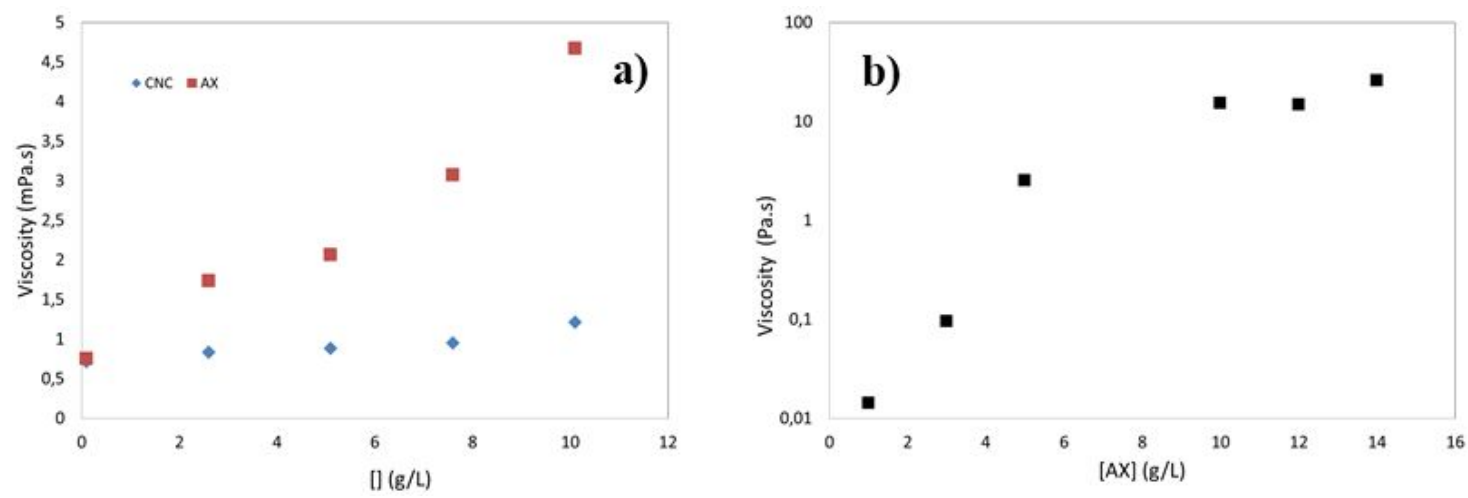

Figure S2. (a) Viscosity vs. concentration for CNC suspensions and AX solutions; (b) Viscosity measurements for solutions containing $10 \mathrm{~g} / \mathrm{L} \mathrm{CNC}$ in the presence of $\mathrm{AX}$ at different concentrations at $20^{\circ} \mathrm{C}$.
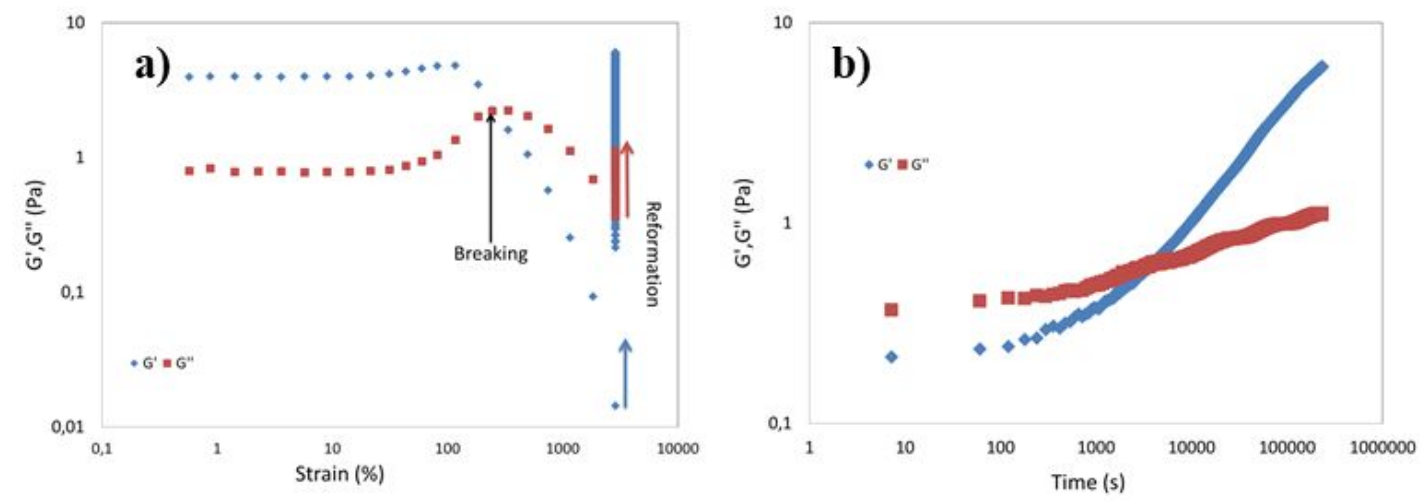

Figure S3. (a) $G^{\prime}$ and $G^{\prime \prime}$ variation as a function of \% strain; and (b) variation of $G^{\prime}$ and $G^{\prime \prime}$ as a function of time after breaking for $10 \mathrm{~g} / \mathrm{L} \mathrm{CNC}+10 \mathrm{~g} / \mathrm{L} \mathrm{AX}$ at $20^{\circ} \mathrm{C}$. 


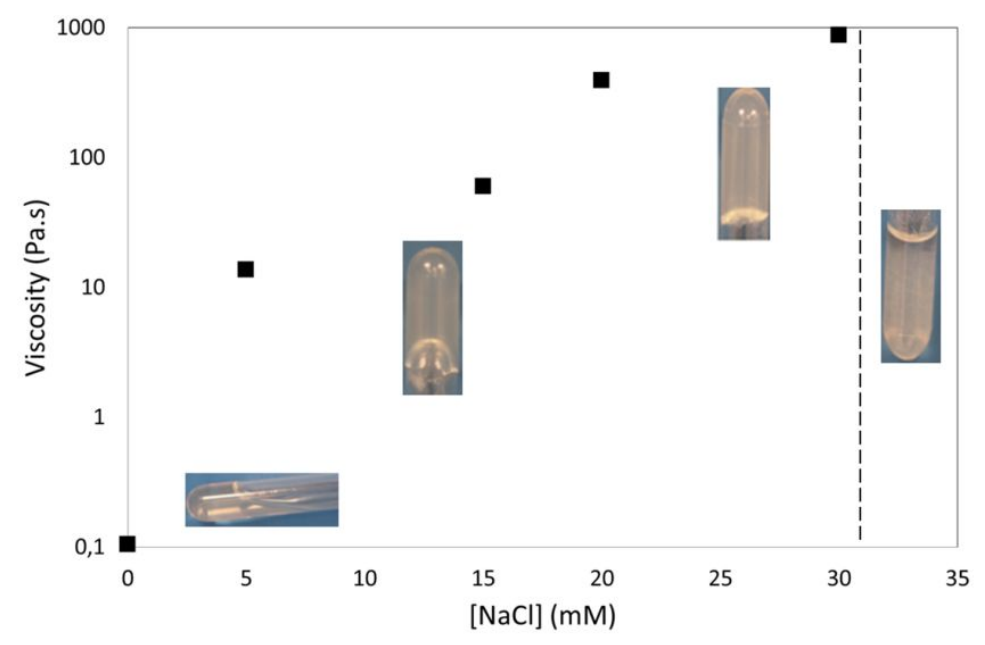

Figure S4. The effect of $\mathrm{NaCl}$ addition on the viscosity of a solution containing $10 \mathrm{~g} / \mathrm{L} \mathrm{CNC}$ $+5 \mathrm{~g} / \mathrm{L} \mathrm{AX}$ at $20^{\circ} \mathrm{C}$, with photos of the resulting mixtures showing the salt effect.
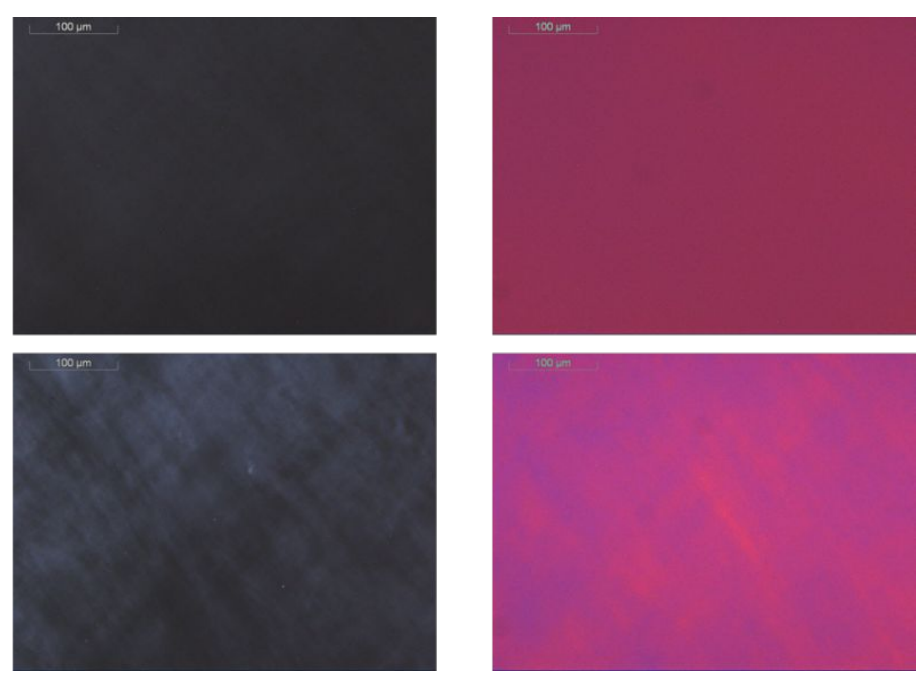

Figure S5. POM images of solution containing $10 \mathrm{~g} / \mathrm{L} \mathrm{CNC}$ and $10 \mathrm{~g} / \mathrm{L} \mathrm{AX}(\mathrm{a}, \mathrm{b})$ before the action of the enzyme, and (c, d) after the action of enzyme with and without the retardation plate. 